\title{
MOTIVASI METRAE DAN NYALENE PADA MASA PERTUNANGAN DI KALANGAN MASYARAKAT MADURA PERSPEKTIF 'URF
}

\author{
Abdul Jalil \& Kholisatun* \\ Institut Agama Islam Negeri Madura \\ Email: jllhasan683@gmail.com
}

\begin{abstract}
Madura region with diverse cultural backgrounds which become its specialty always ignores the attention of researchers to uncover, as it has become unique on most of Madura Island, especially Pamekasan at the time of engagement, a man who has been engaged in carrying out the tradition of carrying out traditions in the form of metrae and nyalene. Metrae and nyalene are usually done by the community in the last 10 months of Ramadan, together with the obligation to issue zakat fitrah for Muslims and end before the Eid Al-Fitr prayers. The submission of pertra and salenan is usually done by the parents of the male fiance, but there is a small portion of the men who are engaged to visit the residence of the female fiance with petra and salenan. Petra and salenan in the form of rice or money worth the petra and the salenan, sometimes in the form of a piece of cloth, a set of clothes or enough money to buy clothes. The tradition of metrae and nyalene is carried out, because it is driven by the desire to help each other and help reduce the burden of the female fiancee, to strengthen the bond of friendship between the two, the love that is being knitted can be bound until the time to hold a marriage contract. By submitting petra and salenan mean to imply that engagement prepared forwarded. Metrae and nyalene both form, scope and motivation of the implementer are included in the 'urf saheeh, namely, customs that apply in the midst of society and do not conflict with the Qur'an and Hadith texts, do not violate religious principles, do not contradict with reason and human mind, does not eliminate prosperity and does not bring harm even, to carry out and preserve this tradition, including carrying out religious principles in the form of help to help.
\end{abstract}

Keywords: 'Urf, metrae, nyalene.

\begin{abstract}
Abstrak
Kawasan Madura dengan latar budaya beragam yang menjadi kekhasannya selalu memantik perhatian para peneliti untuk mengungkap, seperti halnya yang telah menjadi keunikan di sebagian besar Pulau Madura, khususnya Pamekasan pada saat pertunangan, seorang lakilaki yang telah melangsungkan pertunangan menjalankan tradisi berupa metrae dan nyalene. Metrae dan nyalene biasa dilakukan masyarakat pada kurun 10 terakhir bulan Ramadhan, bersamaan dengan kewajiban mengeluarkan zakat fitrah bagi umat muslim dan berakhir sebelum shalat hari raya Idul Fitri dilakukan. Penyerahan pertra dan salenan biasanya dilakukan oleh orang tua tunangan laki-laki namun ada sebagian kecil pihak laki-laki yang bertunangan mengunjungi kediaman tunangan perempuan dengan membawa petra dan salenan. Petra dan salenan berupa beras atau uang yang senilai dengan petra dan salenannya, terkadang berupa sepotong kain, seperangkat pakaian atau uang yang cukup untuk membeli pakaian.
\end{abstract}

* Dosen Fakultas Syariah dan Hukum Institut Agama Islam Negeri (IAIN) Madura. 
Tradisi metrae dan nyalene dilakukan, karena didorong keinginan untuk saling menolong dan membantu mengurangi beban pihak tunangan perempuan, memperkut ikatan silaturahmi antara keduanya, rasa cinta yang tengah dirajut dapat terikat sampai saatnya melangsungkan akad nikah. Dengan menyerahkan petra dan salenan berarti menyiratkan bahwa pertunangannya siap diteruskan. Metrae dan nyalene baik bentuk, cakupan dan motivasi dari pelaksananya termasuk pada 'urf shahih yaitu, kebiasaan yang berlaku di tengah-tengah masyarakat dan tidak bertentangan dengan nash al-Qur'an dan Hadits, tidak menyalahi prinsip agama, tidak bertolak belakang dengan akal dan budi manusia, tidak menghilangkan kemashlahatan dan tidak pula mendatangkan kemudharatan bahkan, menjalankan dan melestarikan tradisi ini termasuk menjalankan prinsip agama berupa tolong menolong.

Kata Kunci: 'Urf, metrae, nyalene.

\section{Pendahuluan}

Allah swt. menciptakan manusia hidup berpasang-pasangan karena demikian sudah menjadi fitrahnya, mereka saling membutuhkan antara satu dengan yang lainnya. Bagi seorang laki-laki belum lengkap dan sempurna hidupnya tanpa kebeadaan perempuan yang mendampingi begitu juga sebaliknya, perempuan tanpa kehadiran sosok laki-laki sebagai pendamping hidupnya belum dikatakan sempurna agamanya. Hidup berpasang-pasang adalah kehendak-Nya. Bahkan, hewan pun Allah swt. ciptakan dengan pasangannya sebagaimana Dia tegaskan dalam firman-Nya surat al-Syũrã:12

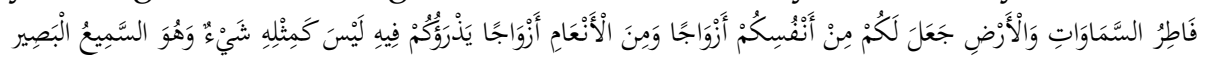

“(Allah) Pencipta langit dan bumi, Dia menjadikan bagi kamu pasang-pasangan dari jenis kamu sendiri, dan dari jenis hewan ternak pasangan-pasangan (juga). Dijadikan-Nya kamu berkembang biak dengan jalan itu. Tidak ada sesuatu pun yang yang serupa dengan Dia, dan Dia yang maha mendengar dan melihat"1

Melalui ibãrat al-nash ${ }^{2}$ ayat di atas sangat jelas bahwa terciptanya keturunan dan anak pinak manusia dengan hidup berpasangan, hal ini terjadi semenjak Allah ciptakan Adam dan Hawa sampai episode terutusnya Nabi Muhammad saw. ke alam semesta. Namun setelah terutusnya Nabi Muhammad saw. satu-satunya cara melestarikan kehidupan dan perkembangbiakan manusia yang dibenarkan Islam yaitu dengan jalan pernikahan ${ }^{3}$

${ }^{1}$ Departemen Agama RI, Al-Qur'ân dan Terjemahnya, (Jakarta: PT. Hati Emas, 2014), hal. 484

2 Penunjukan lafazh atas makna sesuai dengan yang dimaksud secara asalnya, makna tersurat dari sebuah teks. Amir Syarifuddin, Ushul Figh, Vol. 2, (Jakarta: Kencana Prenadamedia, 2008), hlm. 136. Bandingkan dengan Abd Wahhab Khalaf, Ilmu Ushûl al-Fiqh, (tt. Dâr alQalam,1978), hal. 144

${ }^{3}$ Sejarah perkembangbiakan (pernikahan) manusia pra Islam (masa jahiliyah) memiliki bentuk dan macam yang beragam sebagimana riwayat yang dituturkan oleh Siti Aisyah, terdapat empat bentuk. Pertama, nikãh al-ishtishnã', yaitu seorang laki-laki menyerahkan pasangan perempuanya kepada laki-laki lain kemudian digaulinya, setelah ia hamil dengan laki-laki lain tersebut maka perempuan tersebut dapat kembali lagi, ini dilakukan karena laki-laki pertama ingin memiliki anak. Kedua, segolongan laki-laki yang berjumlah 3-9 orang berkumpul dan menuju seorang perempuan kemdian mengaulinya, setelah dinyatakan hamil dan melahirkan, berselang beberapa hari dari kelahiranya, perempuan tersebut mendatangi mereka dengan membawa 
Islam sangat mendorong umatnya untuk membentuk keluarga, mengajak manusia untuk hidup dalam naungan keluarga, karena kehidupan manusia secara individu berada dalam perputaran kehidupan dengan berbagai arah yang menyatu dengannya. Sesungguhnya fitrah kebutuhan manusia menghendaki untuk menuju keluarga sehingga mencapai kerindangan dalam tabiat kehidupan. ${ }^{4}$

Tuntunan Islam mengajarkan, untuk memasuki rumah tangga yang dibingkai dari pernikahan, sangat dianjurkan melewati pintu yang dinamakan khitbah. Aturan pergaulan dalam menciptakan perkenalan antara laki-laki dan perempuan, dimana tahapan umumnya adalah sebagai berikut: pertama, proses ta'ãruf atau perkenalan yang merupakan fase awal sebelum dipinang dengan melalui seorang perantara. Setelah bertemu dan tertarik satu sama lain, dianjurkan untuk dapat mengenal sosok kepribadiannya, terutama agamanya, melacak latar belakang sosial dan budayanya, pendidikan dan asal usul keluarganya, dengan tetap menjaga martabat sebagai manusia yang dimuliakan Allah swt. ${ }^{5}$

Kedua, proses khithbah, yakni melamar atau meminang, disyari'atkannya peminangan sebenarnya dalam rangka mempersiapkan perkawinan yang tidak saja sah menurut syari'at Islam, tetapi bertujuan untuk mengetahui akhlak, karakter dan kepribadian kedua belah pihak agar dikemudian hari tidak muncul kekecewaan lantaran tidak sesuai dengan pasangan yang diidamkan. Hal ini menjadi penting dilakukan guna memantapkan hati dalam menjalani mahligai rumah tangga yang penuh dengan bunga-bunga kasih sayang dan aroma ketentraman. ${ }^{6}$

Masing-masing calon pasangan hendaknya mengembalikan perjanjian ini didasarkan pada pilihannya sendiri karena mereka menggunakan haknya sendiri secara murni, tidak ada hak intervensi orang lain, meskipun wanita terpinang telah menerima berbagai hadiah dari peminang, atau telah menerima hadiah

anaknya seraya berkata kepada mereka "engkau sudah melihat semua, karena ulahmu saya telah melahirkan seorang anak". Kemudian, perempuan ini menunjuk seorang laki-laki untuk menjadi bapaknya dengan menisbatkan nama bayi tersebut kepada laki-laki yang ditunjuk, dan tidak boleh menolaknya karena demikian aturan mainnya. Ketiga, sekelompok laki (tidak terbatas jumlahnya) mendatangi perempuan (pelacur) yang telah memasang papan penunjuk di atas pintu rumahnya, barang siapa yang berkehendak maka dapat masuk kemudian menggaulinya secara bergantian dan perempuan tersebut tidak boleh menolaknya dan keempat, pernikahan yang diawali dengan cara meminang terlebih dahulu (khitbah), baik kepada walinya ataupun langsung pada perempuannya, setelah itu menikahi dan memberi maskawin kepadanya. Setelah panji Islam berkibar dengan pembawa rislahnya Nabi Muhammad saw. Maka tiga model pernikahan tersebut diakhiri dan yang diakui adalah pernikahan yang terakhir sampai pada saat ini. Muhammad bin Ismail Abu Abdillah al-Bukhari, Shahih Bukhari, Vol. 7, (Dar Thuq al-Najah, 1422 H), hal. 15

${ }^{4}$ Ali Yusuf As-Subki, Figh Keluarga (Jakarta: Amzah, 2012), hlm. 23.

${ }^{5}$ Tihami dan Sohari Sahrani, Fikih Munakahat (Jakarta: Rajawali Pers, 2010), hlm. 23.

${ }^{6}$ Wahbah al-Zuhailĩ, Al-Figh al-Islãmĩ wa Adillatuhũ, Juz. 9, (Damaskus: Dar al-Fikr, 2004), hlm. 6492. 
yang berharga sekalipun, semua itu tidak menggeser status pertunangan karena hanya janji untuk menikahi dan dilakukan karena tuntutan maslahat. ${ }^{7}$

Di beberapa daerah meminang memiliki perbedaan yang unik baik dari cara atau pernak perniknya, yang lumrah perwakilan pihak laki-laki mendatangi rumah perempuan dan menyampaikan maksud untuk meminang, berbeda misalnya di Desa Tejosari Kecamatan Laren Kabupaten Lamongan, di desa tersebut perwakilan perempuan yang mendatangi rumah laki-laki untuk meminang. Di Lombok disyaratkan bagi laki-laki harus berani mencuri calon isteri, setelah itu dapat meminang dan bisa menikahi perempuan tersebut.

Lain halnya di daerah Madura, pernak pernik dalam prosesi pertunangan sampai pascapertunangan kerap menghiasi, mulai dari penyerahan cincin kepada terpinang sebagai simbol pengikat, pertukaran cicncin dari peminang dengan terpinag, aneka ragam kue dengan bentuk unik melambangkan pertautan hati yang hendak dirajut, sampai pada buah-buahan juga menjadi pelengkap hantaran dan memiliki makna dan tujuan tersendiri. Pascapertunangan, saat hari-hari besar, sepert hari raya Idul Adlha, Idul Fitri dan Maulid Nabi peminang mengunjungi rumah perempuan yang dipinang dengan membawa aneka kue untuk dipersembahkan kepada keluarga perempuan, bahkan ada di daerah tertentu perempuan yang telah dipinang bisa diajak jalan berdua, silaturrahim dengan kerabat, teman dan famili.

Sebagian besar wilayah di Madura telah berlaku secara turun-temurun tradisi yang unik yaitu metrae ${ }^{8}$ dan nyalene $e^{9}$ selama masa pertunangan. Bahkan Ahmad Saifus Syarif Fadlli dalam Skripsinya tahun 2014 juga telah melakukan penelitian tentang faktor masyarakat melakukan tradisi tersebut berikut dengan pandangan hukum Islamnya ${ }^{10}$. Metrae merupakan pemeberian zakat fitrah yang ditunaikan oleh laki-laki peminang, sementara menurut ketentuan syara' zakat fitrah tersebut kewajiban setiap pribadi muslim, sementara dalam konteks ini seakan-akan laki-laki peminang menanggung beban zakat fitrah perempuan terpinang. Pada biasanya sealain metrae juga nyalene. Dalam hal nyalene ini lakilaki peminang juga menyerahkan seperangkat pakaian lengkap untuk perempuan terpinang atau uang yang senilai dengan seperangkat pakaian yang hendak diberikan kepada pinanangannya.

Hemat peneliti, tradisi metrae dan nyalene patut untuk ditelaah dan diteliti lebih mendalam, karena tradisi ini melekat pada diri masyarakat yang telah

7 Abdul Aziz Muhammad Azzam, Abdul Wahhab Sayyed Hawwas, Fiqh Munakahat, (Jakarta: Amzah, 2011), hlm 8.

${ }^{8}$ Istilah metrae merupakan bahasa Madura yang berasal dari kata petra yang artinya zakat fitrah

9 Istilah nyalene, juga bahasa Madura yang biasa digunakan oleh masyarakat Madura, berasal dari kata salen yang artinya adalah salin atau dandan. Kedua istilah tersebut akan dipaparkan secara rinci pada bagian lain dalam penelitian ini.

${ }_{10}$ Ahmad Saifus Syarif Fadlli, “Tinjauan Hukum Islam terhadap Tradisi Metraeh dan Nyaleneh dalam Masa Pertunagan di Desa Gili Timur Kecamatan Kamal Bangkalan", Skripsi, Juni, 2014. 
terpaut dalam bingkai pertunagan padahal, di sisi lain menunaikan zakat fitrah bukanlah kewajiban laki-laki peminang, termasuk memberikan baju untuk dijadikan pakaian adalah tanggung jawab dan kewajiban orang tua, lebih-lebih ayah masing-masing mereka yang bertunagan. Apa sebenarnya yang menjadi motivasi para orang tua dan orang yang bertunangan metrae dan nyalene pada masa pertunangan? Sependek pemahaman peneliti, pertanyaan tersebut belum terungkap bagaiamana motivasi metrae dan nyalene dan apa yang menjadi pijakan masyarakat Madura metrae dan nyalene pada masa pertunangan baik bagi laki-laki peminang atau keluarganya. Karena itulah peneliti hendak meneliti pertama, Proses metrae dan nyalene pada masa pertunangan. Kedua, Bagaimana motivasi metrae dan nyalene pada masa pertunangan dan ketiga, Bagaimana tinjauan 'urf terhadap motivasi metrae dan nyalene pada masa pertunangan.

\section{Metode Penelitian}

Penelitian ini termasuk pada field research dengan pendekatan kualitatif, sumber data dalam penelitian ini mencakup informasi dalam berbagai bentuk "kata" atau "gambar yang diperoleh melalui wawancara, pengamatan, dokumen. Sumber data primer dalam penelitian ini adalah hasil wawancara dari para orang tua peminang dan peminang sendiri beserta kerabat dekat baik yang sedang menjalani masa tunangan atau yang sudah melewati masa pertunangan yang diambil menurut pola purposif sampling.

Analisis data dilakukan dengan langkah penelaahan, pengelompokan, sistematisasi dan penafsiran data agar sebuah fenomena memiliki nilai sosisal, akademis dan ilmiah. Analisis data dilakukan setelah data yang diperolah dari sampel melalui instrumen yang dipilih kemudian dipilih langkah-langkah tersebut dan kemudian penarikan kesimpulan serta verifikasi.

\section{'Urf Sebagai Dasar Penetapan Hukum}

Kata 'urf berasal dari kata 'arafa, ya'rifu (عرف يعرف) sering diartikan dengan al-ma'rûf "sesuatu yang dikenal". Secara bahasa'urf adalah kebiasaan yang baik"11, sedangkan menurut istilah kata 'urf mengandung makna:

$$
\text { العُرف هو ما تعارفه الناس وساروا عليه، من قول، أو فعل، أو ترك }
$$

"Sesuatu yang sudah dikenal masyarakat dan menjadi kebiasaan mereka,baik berupa perkataan perbuatan atau larangan". ${ }^{12}$

Dari segi objek 'urf meliputi 'urf lafzhî atau qaulî dan 'urf 'amalî. 'Urf lafzhî yaitu kebiasaan masyarakat dalam menggunakan lafazh/perkataan tertentu dalam mengungkapkan sesuatu sehingga makna ungkapan itu yang dipahami dan yang terlintas dalam pikiran masyarakat, misalnya ungkapan "daging"

11 Abd. Rahman Dahlan, Ushul Figh (Jakarta: Amzah, 2014), hlm. 209. Bandingkan Amir Syarifuddin, Ushul Figh, Vol. 2, (Jakarta: Kencana Prenadamedia, 2008), hlm. 387

${ }^{12}$ Abd Wahhab Khalaf, Ilmu Ushûl al-Figh, (tt. Dâr al-Qalam,1978), hal. 89 
hanya tertentu pada daging sapi dan kambing tidak untuk daging ikan atau "engkau saya pulangkan kepada orang tuamu" dalam masyarakat mengandung arti talak. Sementara 'urf 'amalî yaitu kebiasaan masyarakat yang berkaitan dengan perbuatan biasa atau mu'amalah keperdataan, seperti kebiasaan libur kerja pada waktu tertentu dalam satu minggu ${ }^{13}$.

Cakupan 'urf terdiri dari 'urf 'âm, yaitu kebiasaan tertentu yang berlaku secara luas di seluruh masyarakat dan di seluruh daerah, misalnya jual beli mobil, maka semua peralatannya, mulai dari kunci, ban serep, dongkrak termasuk ke dalam harga jual tanpa adanya akad tersendiri. Sementara 'urf khâsh yaitu kebiasaan yang berlaku di daerah atau masyarakat tertentu, misalnya penentuan masa garansi suatu barang ${ }^{14}$.

Aspek keabsahan 'urf terdiri dari dua bentuk. Pertama, 'urf al-shahîh, yaitu kebiasaan yang berlaku di tengah-tengah masyarakat yang tidak bertentangan dengan nash baik al-Qur'an atau Hadits, menghalalkan yang haram tidak mengharamkan yang halal, tiadak menghilangkan kemashlahatan dan tidak pula mendatangkan kemudharatan, misalnya hadiah yang diberikan calon mempelai laki-laki pada mempelai perempuan bukan merupakan mahar. Kedua, 'urf alfâsid yaitu kebiasaan yang sebaliknya 'urf al-shahîh, bertentangan dengan dalildalil syara' dan kaidah-kaidah dasar yang ada dalam syara', misalnya kebiasaan di kalangan pedagang yang menghalalkan riba untuk masalah pinjammeminjam. ${ }^{15}$

\section{Kehujjahan al-'Urf Sebagai Dalil Syara'}

Kehujjahan 'Urf sebagai dalil syara' dapat ditelusuri dalam nash sebagaimana firman Allah swt. dalam surah al-A'raf: 199.

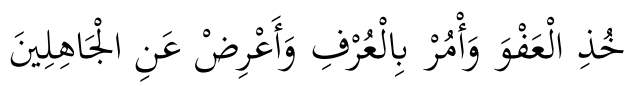

Jadilah engkau pemaaf dan suruhlah orang mengerjakan yang ma'ruf serta berpalinglah dari pada orang-orang yang bodoh. ${ }^{16}$

Berdasarkan ayat di atas Allah swt memerintahkan kaum muslimin untuk mengerjakan yang ma'rüf. Sementara yang disebut sebagai ma'ruf ialah yang dinilai sebagai kebaikan yang dikerjakan secara berulang-ulang dan tidak bertentangan dengan watak manusia yang benar, serta sesuai dengan prinsipprinsip ajaran Islam.

Ungkapan Nabi Muhammad saw. pada Hindun istri Abu Sufyan.

$$
\text { حُذِي مَا يَكْفِيكِ وَوَلَدَكِ بِالْمَعْرُوفِ }
$$

"Ambillah hartanya sekiranya mencukupi untukmu dan anakmu dengan cara $m a^{\prime} r \tilde{u} f^{\prime \prime}{ }^{17}$

${ }^{13}$ Wahbah al-Zuhailî, Ushûl al-Figh al-Islamî, Vol. 2, (Syiria: Dar al-Fikr, 2001), hal.833

${ }^{14}$ Ibid. 834

${ }^{15}$ Nazar Bakry, Ushul Figh (Jakarta: PT Raja Grafindo Persada, 2003) hlm. 236. Cocokkan dengan Wahbah al-Zuhailî, Ushûl, hlm. 835.

${ }^{16}$ Departemen Agama RI, Al-Qur'ân dan Terjemahnya, hal. 176 
Ungkapan Rasulullah saw. بِ بَمَعْرُوفِ pada Hindun dalam Hadits di atas berarti sejumlah harta yang pantas menurut kebiasaan sebagaimana yang dikatakan oleh al-Syaukãnĩ ${ }^{18}$.

Hadits Nabi Muhammad saw.

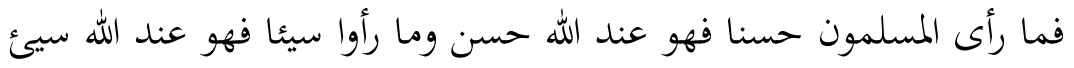

"Sesuatu yang dinilai baik oleh kaum muslimin adalah baik di sisi Allah, dan sesuatu yang mereka nilai buruk maka ia buruk di sisi Allah"19

Berdasarkan dalil-dalil kehujjahan 'urf di atas sebagai dalil hukum, maka ulama terutama Hanafiyah dan Malikiyah merumuskan kaidah hukum yang berkaitan dengan'urf seperti;

"Adat kebiasaan dapat menjadi hukum". ${ }^{20}$

$$
\text { كل ما ورد به الشرع مطلقا ولا ضابط له فيه ولا في اللغة يرجع فيه الى العرف }
$$

Semua ketentuan syara' yang besifat mutlak, dan tidak ada pembatasan di dalamnya, bahkan juga tidak ada pembatasan dari segi kebahasaan, maka pemberlakuannya dirujukkan kepada 'urf. ${ }^{21}$

\section{Metrae, nyalene dan Zakat Fitrah}

Dalam Kamus Bahasa Madura, metrae berasal dari kata petra yang artinya zakat fitrah, sedangkan metrae sendiri memiliki arti menzakat fitrahi ${ }^{22}$, yaitu memberikan sesuatu (baik berupa jagung, beras, atau sejumlah uang) yang bisa dijadikan zakat firah dari pihak laki-laki terhadap seorang perempuan yang sudah menjadi tunangannya, untuk diberikan kepada orang yang berhak menerimanya.

Sementara, nyalene berasal dari kata Salen yang artinya adalah salin atau dandan. Sedangkan Nyalene sendiri memiliki arti menggantikan baju/pakaian, memberi bahan sandang kepada bakal menantu. ${ }^{23}$ Tradisi nyalene dilaksanakan masyarakat biasanya diberikan sebelum hari raya Idul Fitri atau Idul Adlha dengan maksud agar seperangkat pakaian tersebut dipakai oleh tunangannya saat hari raya. Pemberian tersebut dalam konteks Fiqh dapat digolongkan hibah, karena dilakukan secara sukarela, sesuai dengan pengertian hibah berikut ini.

${ }^{17}$ Ibn Mãjah, Sunan Ibn Mãjah, Juz. 2 (tt: Dar ihyã' al-Kutub al-ilmiyah, tt), hal. 769.

${ }_{18}$ Wahbah al-Zuhailî, Ushûl, hlm. 837

${ }_{19}$ Ahmad bin Hanbal Abu Abdullah As Saibani, Musnad al-Imam Ahmad bin Hambal, Juz.1, (Kairo: Muassasah Qartubah, tt), hm. 379.

${ }^{20}$ Abdul Mudjib, Kaidah-kaidah Ilmu Fiqh, (Jakarta: Kalam Mulia, 2001), hlm. 43.

${ }^{21}$ Ibid. 47.

${ }^{22}$ Asis Safioedin, Kamus Bahasa Madura-Indonesia, (Surabaya: CV. Kanendra Suminar), hlm. 179.

${ }^{23}$ Asis Safioedin, Kamus Bahasa Madura-Indonesia, hlm. 197. 
ADHKI: Journal of Islamic Family Law

$$
\text { عقد يفيد تمليك العين بلا عوض ، حال الحياة ، تطوعاً }
$$

"Akad yang menjadikan kepemilikan ketika masih hidup tanpa adanya pengganti dan dilakukan secara sukarela"24

Zakat merupakan salah satu rukun Islam, karenanya meupakan ibadah yang fardlu 'ain bagi setiap manusia yang cukup syarat-syaratnya. Zakat fitrah disyariatkan Allah swt pada bulan Sya'ban tahun kedua hijriyah bersamaan dengan tahun diwajibkannya puasa bulan Ramadlan ${ }^{25}$, dasar kewajiban tersebut sesuai dengan seperti firman Allah swt. dalam surah an-Nisã':77 berikut:

$$
\text { واقيموا الصلاة واتوا الزكاة }
$$

"Dirikanlah shalat dan bayarkanlah zakat hartamu"26.

Zakat fitrah ini merupakan kewajiban atas seluruh umat Islam, untuk dirinya sendiri serta orang-orang yang nafkahnya berada dibawah tanggung jawabnya seperti anak, pembantu dan semua yang diberikan nafkah olehnya. ${ }^{27}$ Kewajiban zakat fitrah ini ditegaskan Oleh Rasulullah saw. dalam Hadits yang diriwayatkan oleh Ibnu Umar:

$$
\text { فرض رسول الله صلى الله عليه وسلم زكاة الفطر صاعا من تمر آو صاعا من شعيرعلى العبد والحر }
$$

Rasulullah saw. Mewajibkan kepada seluruh orang muslim baik kepada orang Islam, laki-laki, perempuan, besar maupun masih kecil, baik budak atau yang merdeka untuk menunaikan zakat fitrah berupa satu shâ'28 dari kurma atau gandum. Dan Rasulullah mewajibkan mengeluarkannya sebelum kaum muslimin menunaikan shalat hari raya idul fitri..29

Hadits lain menyebutkan

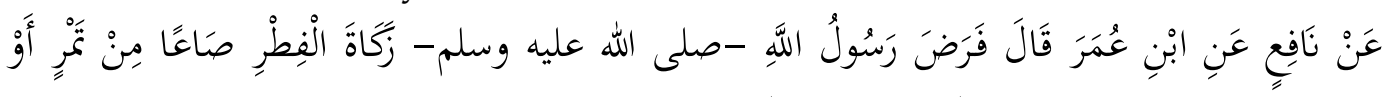

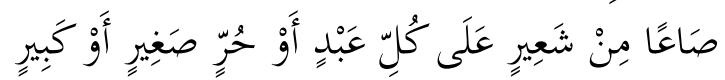

${ }^{24}$ Mustafa al-Khin, al-Fiqh al-Minhâjî alâ Madzhab al-Imâm al-Syafi'î, Juz 6 (Damaskus: Dar al-Qalam, 1982) hlm. 93

${ }^{25}$ Wahbah al-Zuhailî, al-Figh al-Islamî wa Adillatuhû, Juz. 3, (Damaskus: Dâr al-Fikr, 2004), hal.2035

${ }^{26}$ Departemen Agama RI, Al-Qur'ân dan Terjemahnya, hal. 90

${ }^{27}$ Nasar, Problematika Pelaksanaan Fiqh Islam, hlm. 29

${ }^{28}$ Kadar dalam istilah satu shâ' jika dikonversi pada ukuran berat kurang lebih 2,75 liter atau 2176 gram. Jika dibulatkan ukuran beratnya kurang lebih $2.5 \mathrm{~kg}$. lihat Wahbah al-Zuhailî, alFiqh al-Islamî, juz. 1, hal.142

${ }^{29}$ Muhammad bin Ismail Abu Abdillah al-Bukhari, Shahih al-Bukhari, Juz. 2, (tt: Dar Thuq al-Najah, 1422 H), hlm. 130. 
"Dari Nafi' dari Ibn Umar Rasulullah saw. bersabda, Rasulullah memerintahkan membayar zakat fitrah berupa satu shâ' dari kurma dan satu shã' dari gandum bagi tiap manusia merdeka maupun hamba sahaya, baik besar maupun kecil". ${ }^{30}$

\section{Proses metrae dan nyalene pada masa pertunangan di kalangan masyarakat Madura.}

Tradisi metrae dan nyalene pada masa pertunangan sudah dilakukan oleh masyarakat Madura. Tradisi ini dijalankan masyarakat secara turun temurun sejak zaman nenek moyangnya dan hingga saat ini masih terus dilakukan. Sedangkan para muda mudi khususnya yang sedang menjalani masa pertunangan hanya sedikit yang belum mengetahui akan keberadaan tradisi ini, karena itu orang tua dapat mengajarkan pada anak-anaknya akan keberadaan tradisi ini. Keberadaan tradisi tersebut tak ada seorangpun yang berani menolaknya karena hal ini oleh masyarakat sudah dianggap sebagai kebiasaan yang baik dan tidak menimbulkan mudharat, sesuai dengan Hadits:

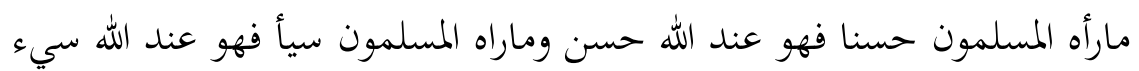

"Sesuatu yang dinilai baik oleh kaum muslimin adalah baik di sisi Allah, dan sesuatu yang mereka nilai buruk maka ia buruk di sisi Allah". ${ }^{31}$

Melestarikan tradisi leluhur merupakan perwujudan dari keteguhan berpegang terhadap ajaran agama karena, ajaran agama yang dibawa dan dibangun oleh Rasulullah juga tidak lepas dari kebiasaan lokal masyarakat. Bahkan pada kasus tertentu, Nabi Muhammad melalui otoritasnya terlibat langsung dalam mengesahkan 'urf, seperti pemberian solusi terhadap kasus yang dialami oleh Hindun dapat diartikan sebagai penjustifikasian 'urf oleh Rasulullah saw. karena, standar nafkah yang patut (ma'ûrf) dan yang cukup (yakfi) tidak dapat diterjemahkan kecuali dengan standar yang berlaku pada kebiasaan masyarakat pada saat itu ${ }^{32}$

Sedangkan proses pelaksanaannya tradisi ini biasa dilakukan pada tanggal 20 bulan Ramadhan kebelakang, karena pada bulan ini berkenaan dengan kewajiban mengeluarkan zakat fitrah bagi umat muslim, serta perintah untuk membayar zakat fitrah adalah sebelum shalat hari raya sesuai dengan hadits Nabi yang diriwayatkan oleh Abdullah bin Umar:

$$
\text { أن رسول الله صلى الله عليه وسلم أمر بزكاة الفطر أن تؤدى قبل خروج الناس الى الصلاة. }
$$

${ }^{30}$ Muslim bin al-Hajjâj al-Naisabûrî, Musnad al-Shahîh al-Mukhtashar bi Naql al-'Adl 'an al'Adl Ila Rasulillah, Juz. 2, (Bairut: Dâr Ihyâ' al-Turâts al-'Arabî, tt), hlm. 677

${ }^{31}$ Abû Abdilah Ahmad bin Muhammad Ahmad bin Hambal, Musnad Ahmad Ibn Hambal, Juz 1, (tt: Muassasah al-Risalah, 2001), hm. 379.

${ }^{32}$ Fauziyah, "Konsep 'Urf Dalam Pandangan Ulama Fiqh” (Telaah Historis), Nuraini, Vol 14 Nomor 2 (Desember, 2014) hlm. 18 
"Rasulullah SAW memerintahkan pembayaran zakat fitrah sebelum orangorang keluar dan melaksanakan shalat hari raya". ${ }^{3}$

Sedangkan pelaksanaannya yaitu orang tua tunangan laki-laki mengunjungi kediaman tunangan perempuan dengan membawa petra dan salenan yang kemudian diterima oleh calon besan. adapun bentuknya bermacammacam yaitu bisa berupa jagung, beras, atau uang untuk petra. Karena zakat fitrah yang harus dikeluarkan adalah makanan pokok sedang jagung ataupun beras merupakan bagian dari makanan pokok, seperti yang telah disyaratkan oleh golongan Maliki, bahwa makanan pokok itu harus yang termasuk dalam Sembilan asnaf, sebagaimana ditetapkan mereka, yaitu: sya'ir, kurma basah, kurma kering, gandum, biji-bijian, salt, padi, susu kering dan keju. ${ }^{34}$ Hal ini sesuai dengan hadits nabi berikut:

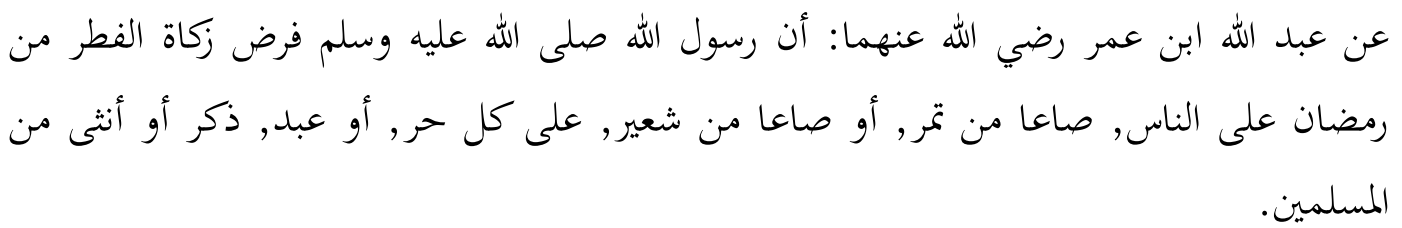

"Dari Abdullah bin Umar RA, bahwa Rasulullah mewajibkan zakat fitrah dibulan Ramadhan bagi kaum muslimin, yang terdiri dari satu shâ' kurma atau satu shâ' gandum. Baik untuk orang merdeka, hamba sahaya, laki-laki atau wanita dari kaum muslimin". ${ }^{35}$

Sesungguhnya, Nabi Muhammad saw. membatasi zakat fitrah pada makanan-makanan tertentu saja, karena makanan tersebut pada waktu itu merupakan makanan pokok di lingkungan Arab. Andaikan orang-orang makanan pokoknya beras seperti di Jepang, tentu itu yang diwajibkan, demikian pula jagung seperti dipesisir mesir. Karena yang paling baik adalah seseorang mengeluarkan zakat fitrah makanan pokoknya atau makanan pokok daerahnya, tergantung mana yang paling utama. ${ }^{36}$ Sedangkan zakat fitrah yang menggunakan uang atau nilai dari makanan pokok tersebut, terdapat sialang pendapat di antara fuqaha bahwa mengeluarkan nilai zakat (bukan barangnya) menurut Imam Malik, Imam Syaf'i dan Imam Ahmad ibn Hambal tidak diperkenankan, baik pada zakat fitrah maupun pada zakat-zakat lainnya.

Imam Ahmad telah bertanya kepada Imam 'Atha tantang mengeluarkan beberapa dirham untuk zakat fitrah. Ia menjawab: Aku kuatir tidak diperkenankan, karena bertentangan dengan sunah Rasulullah saw. Dinyatakan kepadanya: Bukankah orang-orang berkata bahwa Umar bin Abdul Aziz telah mengambil harga zakat? 'Atha berkata: "Mereka meninggalkan ucapan Rasulullah saw. dan mengambil pendapat seseorang? Ibnu Umar berkata: "Rasulullah saw. telah mewajibkan zakat fitrah satu shâ' kurma atau satu shâ'

\footnotetext{
${ }^{33}$ Muhammad Nashiruddin Al Albani, Mukhtashar Shahih Muslim, hlm. 384.

34 Yusuf Qardawi, Hukum Zakat, hlm. 951.

${ }^{35}$ Muhammad Nashiruddin Al Albani, Mukhtashar Shahih Muslim, hlm. 383.

${ }^{36}$ Yusuf Qardawi, Hukum Zakat, hlm. 953.
} 
gandum....." dan Allah swt. berfirman "Taatilah Allah dan taatilah Rasulnya". Jadi menurut Ibnu Umar menyerahkan harga itu bertentangan dengan sunah Rasulullah saw. Demikian juga pendapat Imam Malik dan Imam Syafi'i.

Adapun menurut Abu Hanifah dan ashabnya berpendapat, bahwa mageluarkan harganya itu diperbolehkan. Hal itu diriwayatkan dari Umar bin Abdul Aziz serta Hasan Basri.

Riwayat Ibnu Abu Syaibah, ia berkata: "Aku telah mendengar surat Umar bin Abdul Aziz yang dibacakan pada 'Abdi, Gubernur Basrah, bahwa diambil dari gaji pagawai kantor, masing-masing setengah dirham. Imam Hasan berkata : "Tidak mengapa dikeluarkan beberapa dirham zakat fitrah".

Alasan yang memperkuat pendapat ini adalah sabda Rasulullah SAW: "Cukupkan orang-orang miskin pada hari raya ini, jangan sampai memintaminta." Mencukupkan itu bisa dengan harganya, bisa pula dengan makanannya. Kadangkala harganya itu lebih utama, sebab terlalu banyak makanan pada orang fakir menyebabkan keinginan untuk dijual, sedangkan apabila harganya, si fakir bisa mempergunakannya untuk membeli segala keperluannya seperti makanan, pakaian dan kebutuhan lainnya.

Ibnu Mundzir mengemukakan, bahwa kebolehan mengeluarkan harga itu, sudah ditunjukkan sejak dari dahulu, yaitu para sahabat memperbolehkan mengeluarkan setengah shâ gandum, karena dianggap sama nilainya dengan satu shấ kurma atau satu shâ' gandum.

Pemberian dengan harganya ini lebih mudah di zaman kita sekarang ini, dan terutama di lingkungan negara industri, di mana orang-orang tidaklah bermuamalah, kecuali dengan uang, sebagaimana pula di sebagian besar Negara dan pada biasanya, lebih bermanfaat bagi orang-orang fakir. Sesungguhnya yang tampak bagi saya, bahwa Rasulullah SAW itu mewajibkan zakat fitrah dengan makanan, karena dua sebab:

Pertama, jarangnya mata uang di tanah Arab ketika itu, sehingga dengan memberi makanan itu, akan lebih memudahkan bagi orang banyak. Kedua, sesungguhnya nilai uang itu berubah dan berbeda daya belinya dari satu masa pada masa yang lain, berbeda dengan satu shâ' makanan yang secara pasti mengenyangkan orang, sebagaimana makanan pada masa itu lebih mudah bagi orang yang memberi dan lebih bermanfaat bagi orang yang menerima. ${ }^{37}$

Salenan yang lumrah diberikan masyarat terkadang berupa sepotong kain, seperangkat pakaian, atau uang yang cukup untuk membeli pakaian yang nantinya akan dikenakan ketika berkunjung ke rumah tunangan laki-laki saat hari raya Idul Fitri tiba. Karena hari raya merupakan hari kemenangan bagi umat muslim setelah sebulan lamanya menahan lapar, haus, serta hawa nafsu, untuk itu pada hari tersebut memang dianjurkan oleh Allah untuk mengenakan pakaian yang baik dan bagus.

${ }^{37}$ Ibid. hlm, 955-956. 
Adapun kehendak untuk melakukan tradisi ini kebanyakan bukan kehendak dari pihak tunangan, akan tetapi dari orang tuanya, biasanya orang tua memberitahukan sebelum bulan Ramadhan tiba sehingga tunangan laki-laki akan mempersiapkan segalanya. Keberadaan tradisi ini mengajarkan pihak lakilaki bertanggung jawab kepada calon istri, sehingga nanti setelah menikah benar-benar siap mental untuk menjadi imam yang bertanggung jawab bagi keluarga. Sebagaimana firman Allah al-Baqarah: 233

$$
\text { وعلى المولود له رزقهن وكسوةن بالمعروف }
$$

"Dan kewajiban ayah (suami) memberi makan dan pakaian kepada para ibu (istri) dengan cara yang baik." 38

Pelaksanaan tradisi metrae dan nyalene adakalanya diantarkan sendiri oleh yang bersangkutan yaitu tunangan laki-laki, dan ada pula sepasang tunangan itu pergi membeli salenan-nya ke toko pakaian tentunya disertai mahramnya. hal ini diperbolehkan dalam Islam karena tidak berkhalwat.

Tunangan yang dalam istilah fiqh disebut khitbah bukan merupakan pernikahan, namun hanyalah sekedar janji untuk menikah. Oleh karenanya, ketentuan hukum dalam pernikahan belum berlaku sedikitpun. Berkhalwat atau menyendiri dengan perempuan tersebut masih tetap terlarang. Karena ia masih merupakan perempuan asing dan belum halal bagi lelaki yang mengkhitbahnya. Dalam beberapa Hadits Rasulullah saw. telah melarang berkhalwat dengan perempuan asing (bukan mahram) dan duduk berdua dengannya. kecuali jika dibarengi oleh mahramnya seperti ayah, saudara, atau pamannya. ${ }^{39}$ Seperti dalam Hadits berikut:

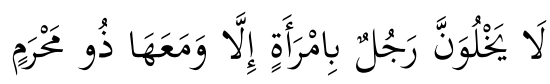

"Janganlah seorang lelaki berduaan dengan seorang perempuan kecuali dibarengi oleh mahramnya". 40

Menurut ulama Syafi'iyah, ketika berinteraksi dengan perempuan hanya boleh melihat wajah saja. Sedangkan menurut para ulama Hanabilah boleh melihat wajah dan kedua telapak tangan. Tidak boleh melihat lebih dari sekali kecuali memang membutuhkan lagi melihat kedua kalinya untuk memastikan, maka itu boleh. ${ }^{41}$ Adapun Ulama Malikiyah juga berpendapat bahwa, boleh melihat wajah dan kedua telapak tangan calon istri sebelum akad nikah. Hal itu untuk mengetahui hakikat keadaan calon istrinya tersebut, baik dari dia langsung atau dari walinya. ${ }^{42} \mathrm{Hal}$ ini sesuai dengan firman Allah surat al-Nur; 31:

${ }^{38}$ Departemen Agama RI, Al-Qur'ân dan Terjemahnya, hal. 37.

${ }^{39}$ Wahbah al-Zuhailî, al-Figh al-Islamî, Juz. 3, hal. 35.

${ }^{40}$ Muslim bin al-Hajjâj al-Naisabûrî, Musnad al-Shahîh al-Mukhtashar bi Naql al-'Adl 'an al'Adl Ila Rasulillah, Juz. 2, (Bairut: Dâr Ihyâ' al-Turâts al-'Arabî, tt), hal. 978

${ }^{41}$ Ibid. 32.

${ }^{42}$ Ibid. 35. 


$$
\text { ولا يبدين زينتهن إلا ما ظهرمنها }
$$

"Dan janganlah (kaum wanita) menampakkan perhiasannya, kecuali yang (biasa) tampak daripadanya". 43

Dalam tradisi pemberian petra dan salenan tidak ada yang bertentangan dengan nash, hal itu hanyalah pemberian (hibah) semata yang masuk dalam ruang lingkup 'urf, karena ini merupakan adat/kebiasaan yang terjadi di masyarakat, hibah memang dianjurkan dalam syariat Islam, namun pada proses pelaksanaannya yang terkadang ada sedikit yang perlu untuk diluruskan, yaitu mengenai turut hadirnya tunangan laki-laki ke rumah tunangan perempuan. Seperti halnya yang telah disebutkan sebelumnya bahwa hakikat pertunangan hanyalah sekedar janji untuk menikah, belum terikat dengan hak dan kewajiban atas masing-masing tunangannya, jadi mereka dilarang berkhalwat atau berduaan tanpa disertai mahram, namun jika disertai mahram hal ini diperbolehkan itupun hanya sekedar melihat wajah dan kedua telapak tangan, tidak lebih dari itu.

\section{Motivasi metrae dan nyalene pada masa pertunangan di kalangan masyarakat Madura}

Motivasi masyarakat cukup beragam dalam melestarikan tradisi metrae dan nyalene oleh tunangan laki-laki terhadap tunangan perempuan, hal ini merupakan kebiasaan yang sudah menjadi tradisi masyarakat. Bentuk tradisi yang demikian akan mempererat hubungan keluarga antara kedua belah pihak sebab disitulah terjalin silaturahmi. Sebuah tradisi boleh dilaksanankan apabila tidak ada mudharat, sebaliknya jika ada mudharat maka tidak boleh dilaksanakan. Firman Allah swt pada surah al-A'raf: 199.

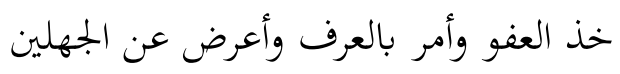

Jadilah engkau pemaaf dan suruhlah orang mengerjakan yang ma'ruf serta berpalinglah dari pada orang-orang yang bodoh. ${ }^{4}$

Berdasarkan ayat di atas Allah swt memerintahkan kaum muslimin untuk mengerjakan yang ma'ruf . sedangkan yang disebut sebagai ma'ruf ialah yang dinilai sebagai kebaikan yang dikerjakan secara berulang-ulang dan tidak bertentangan dengan watak manusia yang benar, serta sesuai dengan prinsipprinsip ajaran Islam. Tradisi ini tidak menimbulkan akibat hukum, Seperti halnya yang tercantum dalam KHI pasal 13 ayat (1) berikut isinya:

Pinangan belum menimbulkan akibat hukum dan para pihak bebas memutuskan hubungan peminangan. ${ }^{45}$

\footnotetext{
${ }^{43}$ Departemen Agama RI, Al-Qur'ân dan Terjemahnya, hal. 353

${ }^{44}$ Departemen Agama RI, Al-Qur'ân dan Terjemahnya, hal. 176

45 Tim Redaksi Nuansa Aulia, Kompilasi Hukum Islam (Bandung: CV Nuansa Aulia, 2012), hlm. 33
} 
Akan tetapi jika salah seorang tidak melaksanakan tradisi/adat tersebut maka ia akan menerima cemooh serta jadi pembicaraan masyarakat dan keluarga karena hal ini dianggap menyalahi aturan tingkah laku yang disebut tengka.

Tradisi ini akan menjadi simbol akan keberlanjutan hubungan pertunangan, karena jika tradisi ini tidak dilakukan, maka pihak tunangan perempuan menganggap dari pihak tunangan laki-laki sudah tidak berkehendak untuk melanjutkan hubungan pertunangan ini, untuk itu biasanya dari pihak tunangan perempuan akan mendatangi pihak tunangan laki-laki untuk ngettoseh (menanyakan tindak selanjutnya dari hubungan pertunangan). Jika tidak ada respon positif maka pihak tunangan perempuan akan membatalkan hubungan pertunangan tersebut. Pada tataran ini keengganan dalam menjalankan tradisi metrae dan nyalene telah dianggap oleh masyarakat khususnya pada masyarakat Madura telah berakhir hubungan pertunangan antara mereka, hal ini selaras dengan bunyi KHI pasal 13 ayat (2) yaitu:

Kebebasan memutuskan hubungan peminangan dilakukan dengan tata cara yang baik sesuai dengan tuntunan agama dan kabiasaan setempat, sehingga tetap terbina kerukunan dan saling menghargai. ${ }^{46}$

Sementara pemberian petra dan salenan menurut ajaran agama termasuk dalam ruang lingkup hibah, diamana Allah swt. mensyariatkan hibah karena dapat menguatkan tali kasih di antara sesama dan mempererat persaudaraan. Diriwayatkan dari Abu Hurairah bahwa Rasulullah SAW bersabda:

$$
\text { قادوا تحابوا. }
$$

"Saling memberi hadiah dapat menguatkan ikatan cinta yang tertanan dalam setiap manuasia"47.

$$
\text { قادوا فإن الهدية تذهب وحر الصدر }
$$

"Saling memberi hadiah dapat memadamkan rasa kedengkian dan kebencian dalam hati"48

Namun, terdapat konsekwensi hukum yang bersoal jika pertunangan harus diakhiri terhadap status dari pemberian petra dan salenan, ini disebabkan karena terdapat persinggungan dari pemberian tersebut antara hibah dan hadiah. Maka, menurut ulama Hanafiyah hukum hadiah sama seperti hukum hibah (pemberian), oleh karenanya bagi peminang boleh meminta kembali pemberian tersebut, kecuali ada yang mencegah atau terhalang seperti barangnya rusak atau dilebur. Jika hadiah berbentuk seperti cincin, jam, bahan pakaian dan atau makanan, peminang memiliki peluang dan diperkenankan meminta kembali selama barangnya masih ada. Jika barangnya telah rusak, tercampur dengan barang lain atau berubah keadaannya, misalnya cincin hilang,

${ }^{46}$ Ibid

${ }^{47}$ Abu Bakar al-Baihaqî, Al-Sunan al-Kubrâ, Juz 6, (Bairut: Dâr al-Kutub al-`Ilmiyah, 2003), hal. 289

${ }^{48}$ Muahammad bin Îsâ Abû Îsâ al-Tirmîdzî, Al-Jâmi' al-Shâhîh Sunan al-Tirmîdzî, Juz 4, (Bairut: Dâr Ihyâ' al-Turâts al-'Arabî, tt), hal. 441 
bahan sudah dijahit menjadi pakaian atau makanan sudah habis dimakan, maka peminang tidak berhak meminta kembali, baik barangnya ataupun harganya. Menurut ulama Hanafiyah, sebagaimana barang hibah yang telah rusak atau terlebur tidak boleh diminta kembali demikian juga barang hadiah mempunyai hukum yang sama, tidak boleh diminta kembali. ${ }^{49}$

Ulama Syafi'iyah berpandangan bahwa si laki-laki boleh meminta kembali hadiah yang telah ia berikan, karena ia memberi itu hanya untuk menikahi perempuan tersebut. Jika hadiah tersebut masih ada maka ia boleh memintanya kembali. Namun, jika hadiah tersebut telah rusak maka ia boleh meminta gantinya.

Sedangkan menurut ulama Malikiyah, jika pembatalan Khitbah itu dilakukan oleh pihak lelaki maka ia tidak berhak meminta kembali sedikitpun. Akan tetapi jika pembatalan tersebut dari pihak perempuan maka si lelaki boleh meminta kembali hadiah-hadiah yang telah ia diberikan. Ini yang benar dan adil, karena itu merupakan pemberian dengan syarat akadnya tetap. Jika akad tersebut tiada maka si pemberi boleh meminta hadiahnya kembali atau semisalnya. ${ }^{50}$

Masyarakat Madura yang hendak bertunangan menyadari dan menerima semua konsekuensi yang timbul setelah pertunangan termasuk pemberian petra dan salenan terhadap tunangannya, untuk itu tradisi metrae dan nyalene tidak menjadi beban bagi kalangan masyarakat. Bahkan sebaliknya, masyarakat sangat mengapresiasi dengan adanya tradisi tersebut karena hal tersebut sangat membantu meringankan tanggung jawab orang tua. Pihak tunangan perempuan merasa terbantukan dengan adanya tradisi metrae dan nyalene, sementara pihak tunangan laki-laki merasakan kebahagian yang sama dapat membantu pihak tunagan perempuan yang pada akhirnya terwujud adanya saling tolong menolong di antara kedua calon besan. Sementara tolong-menolong sangat dianjurkan oleh Allah swt., bahkan dalam firman-Nya Allah menyebut dengan ujaran perintah yang dalam istilah Ushul Fiqh kalimat perintah menunjukkan suatu kewajiban selama tidak ada dalil lain yang memalingkan. Allah swt. Berfirman dalam surat al-Maidah: 2

$$
\text { وتعاونوا على البر والتقوى ولا تعاونوا على الاثم والعدوان, والتقوا الله إن الله شديد العقاب }
$$

“Dan tolong menolonglah kamu dalam (mengerjakan) kebajikan dan takwa, dan jangan tolong menolong dalam berbuat dosa dan pelanggaran. Dan bertakwalah kamu kepada Allah, sesungguhnya Allah amat berat siksanya". ${ }^{51}$

Mengingat dalam Ushul Fiqh terdapat kaidah bahawa "bentuk nash perintah menunjukkan kewajiban selama tidak ada dalil yang memalingkan" seperti

\section{${ }^{49}$ Abdul Aziz Muhammad Azzam, Abdul Wahhab Sayyed Hawwas, Fiqh Munakahat, hlm.}

${ }^{50}$ Wahbah Az-Zuhaili, Fiqih Islam wa Adillatuhu jilid 9, hlm. 37.

${ }^{51}$ Departemen Agama RI, Al-Qur'ân dan Terjemahnya, hal. 106 
tolong menolonglah kalian ${ }^{52}$ maka, membantu meringankan beban pihak tunangan dengan memberi petra dan salenan termasuk perbuatan yang sangat dianjurkan, sebaliknya mengabaikan anjuran Allah berarti telah lalai terhadap ajaran agama, hal ini sejalan dengan penilaian masyarakat terhadap pihak lakilaki yang enggan menjalankan tradisi berupa memberi petra dan salenan terhadap tunangannya akan memperoleh cacian dari masyarakat khususnya dari pihak perempuan.

Pelaksanaan tradisi metrae dan nyalene ini hanyalah berupa hibah semata yang jika terjadi pembatalan pertunangan tidak ada yang pernah mengembalikan ataupun yang memintanya. Sedangkan petra tersebut ketika hendak ditunaikan sebagai zakat fitrah oleh tunangan perempuan, ia tetap berniat dari dirinya sendiri yang mengeluarkan bukan dari tunangan laki-laki. Tradisi ini perlu untuk tetap dilestarikan karena masyarakat menganggap bahwa ini merupakan tradisi yang baik dan memiliki tujuan luhur sesuai dengan ucapan sahabat Rasulullah saw, Abdullah bin Mas'ud.

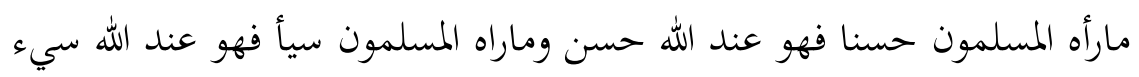

"Sesuatu yang dinilai baik oleh kaum muslimin adalah baik di sisi Allah, dan sesuatu yang mereka nilai buruk maka ia buruk di sisi Allah". ${ }^{53}$

\section{Tinjauan 'urf terhadap motivasi metrae dan nyalene pada masa pertunangan di kalangan masyarakat Madura}

Melihat 'urf beserta pergerakannya tentu mendapati 'urf tersebut dinamis dan dapat berubah, ia tidak statis ataupun stagnan, kendati adakalanya berubah dengan sangat lambat. ${ }^{54}$ Tetapi zaman selalu berubah dan lingkungan pun ikut berubah, termasuk wawasan dan pemikiran manusianya pun berubah. Konsekuensinya, metode dan cara yang dipakai manusia berubah, sesuai dengan kemampuan dan kesanggupannya. Karenanya, tidaklah aneh jika 'urf dan adat dan kebiasaan mereka juga berubah.

Sebagaimana terjadi pada bentuk metrae dan nyalene, pada zaman dulu metrae berupa jagung disesrahkan kepada pihak tunangan perempuan namun, dalam perkembangannya sampai sekarang petra yang diberikan pihak laki-laki pada tunangan perempuan berupa beras, termasuk salenan-nya. Pada zaman dulu hanya berupa sepotong kain yang diserahkan kepada pihak tunangan untuk dapat dijahit menjadi baju, namun sekarang berubah menjadi seperangkat baju jadi bahkan lengkap dengan kerudung dan sandalnya.

'Urf juga merupakan hujjah, bahkan lebih mudah untuk dipahami. Sebagaimana Abdul Wahhab Khallaf menyebutkan:

${ }^{52}$ Al-Maidah (5): 2

${ }^{53}$ Abu Abdilah Ahmad bin Muhammad Ahmad bin Hambal, Musnad Ahmad Ibn Hambal, Juz 1, (tt: Muassasah al-Risalah, 2001), hal. 379.

54 Sirajuddin M, “Eksistensi 'Urf Sebagai Sumber Pelembagaan Hukum Nasional”, Madania, Vol. 19, No. 1, (Juni, 2015) hlm. 15 


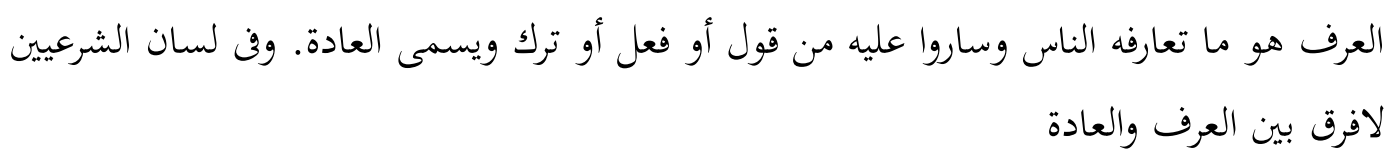

"Sesuatu yang telah diketahui oleh orang banyak dan dikerjakan oleh mereka, baik dari perkataan, perbuatan dan atau sesuatu yang ditinggalkan. 'Urf ini sama halnya dengan adat dan kebiasan karena itulah menurut dalam istiah syara' keduanya tidak ada perbedaan. ${ }^{55}$

Antara 'urf dan 'âdah keduanya harus betul-betul telah berulang-ulang dikerjakan oleh manusia, sehingga melekat pada jiwa, diterima dan dibenarkan oleh akal sehat manusia sesuai tabiat aslinya. ${ }^{56}$

Adapun kebiasaan masyarakat Madura yang berkenaan dengan metrae dan nyalene juga merupakan bentuk 'urf karena hal ini di lakukan berulang-ulang sejak zaman dahulu, serta dapat dibenarkan dan diterima oleh akal sehat dan tradisi ini sudah mendarah daging dan melekat dalam jiwa masyarakat sehingga, apabila meninggalkannya masyarakat menganggap telah melanggar aturan tingkah laku sosial yang di sebut tengka dan ia akan menerima cemoohan dan cacian dari masyarakat sekitar dan bahkan lebih dari hanya cacian, hubungan pertunangannya akan dianggap putus.

Salah satu kaidah utama dalam fiqh yang disepakati para ahli fiqh dari berbagai madzhab adalah menjadikan kebiasaan dan tradisi masyarakat setempat sebagai landasan hukum, selama itu tidak menyalahi syariat. Karena itulah mereka menjadikan kaidah العادة معكمة (tradisi/kebiasaan dapat dijadikan ketetapan hukum) sebagai salah satu kaidah pokoh dan ketentuan yang disepakati secara umum. ${ }^{57}$ Dasar kaidah tersebut sebagaimana Hadits berikut:

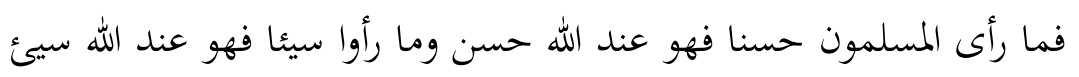

"Sesuatu yang dinilai baik oleh kaum muslimin adalah baik di sisi Allah, dan sesuatu yang mereka nilai buruk maka ia buruk di sisi Allah". ${ }^{58}$

Melihat dari apa yang dibiasakan masyarakat berupa metrae dan nyalene menurut peneliti termasuk perbuatan yang baik bahkan terpuji. Secara syara' memiliki kesesuaian dengan ajaran agama Islam. Islam mengajarkan saling tolong menolong, dengan metrae dan nyalene jelas terdapat unsur saling menolong, saling meringankan beban orang lain walaupun tidak tersurat saat menyampaikan petra dan salenan.

55 Abd Wahhab Khalaf, Ilmu Ushûl al-Fiqh, (Dâr al-Qalam,1978), hal. 89 bandingkan dengan Abdul Mudjib, Kaidah-kaidah Ilmu Figh, hlm. 45.

${ }^{56}$ Ibid.

${ }^{57}$ Yusuf Al-Qaradhawi, 7 Kaidah Utama Fiqh Muamalat (Jakarta: Pustaka Al-Kautsar, 2014), hlm. 228.

${ }^{58}$ Ahmad bin Hanbal Abu Abdullah As Saibani, Musnad al-Imam Ahmad bin Hambal, Juz.1, (Kairo: Muassasah Qartubah, tt), hm. 379. 
Rasulullah saw. pun mengajarkan kepada umatnya untuk merajut dan menjaga hubungan siltarrahim antara sesama muslim. Menjaga silaturrahim dapat dilakukan dengan cara saling membantu, memberi, menghadiahi dan mengasihi. Dengan cara tersebut rasa cinta yang tertanan dalam hati-hati masing-masing dapat terjaga dan tambah kuat, termasuk dalam hati calon besan dan hati laki-laki bersama perempuan yang menjalin pertunangan. Sebagaimana sabda-Nya

"Saling memberi hadiah dapat menguatkan ikatan cinta yang tertanan dalam setiap manuasia"59.

Memandang tradisi metrae dan nyalene dapat dikategorikan pada 'urf 'amalî yaitu berupa kebiasaan masyarakat yang berkaitan dengan perbuatan yang berkaitan dengan keperdataan. Metrae dan naylene adalah aktivitas perbuatan non-verbal yang sudah mengakar pada kehidupan masyarakat. Mengacu pada tradisi metrae oleh tunangan laki-laki terhadap tunangan perempuan dapat dipadankan dengan konsep hibah yaitu pemeberian sukarela terhadap tunanagnnya, setelah pemberian tersebut diterima pihak perempuan menjadikan pemeberian tersebut sebagai zakat fitrah dirinya untuk kemudian diserahkan kepada orang yang berhak menerima. Hal ini sesuai dengan ketentuan dalam penunaian zakat fitrah yang salah satu syarat sahnya adalah niat atau maksud menunaikan zakat fitrah.

Sesungguhnya zakat fitrah ini merupakan kewajiban atas seluruh umat Islam, untuk dirinya sendiri serta orang-orang yang nafkahnya berada dibawah tanggung jawabnya seperti anak, pembantu dan semua yang diberikan nafkah olehnya. ${ }^{60}$ Kewajiban untuk zakat fitrah ini tertuang dalam Hadits yang diriwayatkan oleh Ibnu Umar:

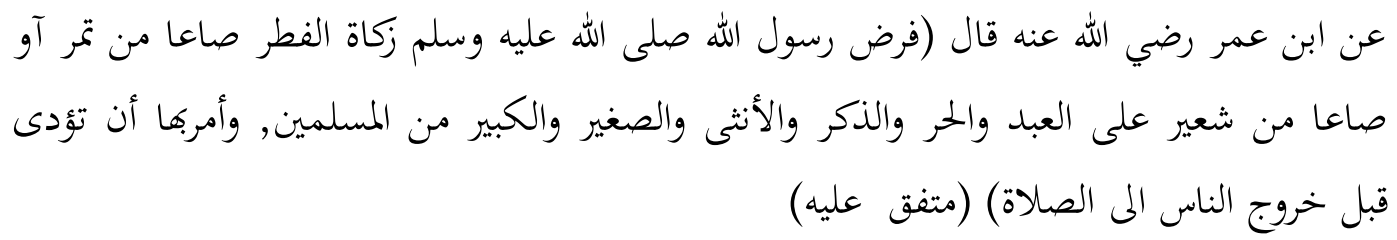

Dari Ibnu Umar Ra. Dia Berkata Rasulullah SAW memerintahkan kami mengeluarkan zakat fitrah orang yang menjadi tanggungan, yang kecil, yang besar, yang merdeka dan yang budak. ${ }^{61}$

Adapun pemberian pertra dan salenan adalah tradisi sebagai bentuk kepedulian terhadap tunangan perempuan, bukan termasuk tanggung jawab yang harus dipenuhi oleh tunangan laki-laki yang seperti halnya tanggung jawab atas orang tua/wali dari tunangannya. Jadi, tradisi ini merupakan ke-khas-an yang dimiliki oleh masyarakat tertentu walaupun bukan menjadi tanggungan atau kewajiban tapi masarakat dengan sukarela melaksanakan dan hal. 289

${ }^{59}$ Abu Bakar al-Baihaqî, Al-Sunan al-Kubrâ, Juz 6, (Bairut: Dâr al-Kutub al-`Ilmiyah, 2003),

${ }^{60}$ Ibid.

${ }^{61}$ Al-Hafidz Ibnu Hajar Al-Atsqalani, Bulughul Maram (Surabaya: Al-Hidayah), hlm. 131. 
melestarikannya. Oleh karena itu, jika dilihat dari segi cakupannya tradisi ini termasuk pada 'urf khash yaitu kebiasaan yang berlaku di daerah atau masyarakat tertentu dan tidak berlaku pada masyarakat lain.

Sebagai bentuk 'urf yang terkategori perbauatan ('amalî) dan terbingkai pada lingkup tertentu atau khusus, kebiasaan ini akan menjadi dasar dan penguat dalam penetapan hukum, tentu jika tradisi ini sah menurut pandangan syara'. Sedangkan jika dilihat dari segi keabsahannya metrae dan nyalene baik bentuk, cakupan dan motivasi dari pelaksananya termasuk pada 'urf shahih yaitu kebiasaan yang berlaku di tengah-tengah masyarakat dan tidak bertentangan dengan nash al-Qur'an dan Hadits, tidak menyalahi prinsip agama, tidak bertolak belakang dengan akal dan budi manusia, tidak menghilangkan kemashlahatan dan tidak pula mendatangkan kemudharatan bagi masyarakat, karena itu pula, menjalankan dan melestarikan tradisi ini termasuk menjalankan prinsip agama berupa tolong menolong, mendatangkan kemashlahatan bersama sebagai penguat tali persaudaraan dan pengikat hubungan pertunangan sampai kelak menuju jenjang pernikahan, menepis anggapan jelek masyarakat berupa cacian sesuai dengan akal dan budi masyarakat.

'Urf dapat diindahkan tidak lain karena ia mencerminkan kebutuhan masyarakan, mencerminkan apa yang mereka akui bersama. Karenanya, alasan syariat memerhatikannya tidak lain pula karena untuk memenuhi kebutuhankebutuhan yang merupakan bagian dari maslahat atau kepentingan masyarakat. Pasalnya, syariat hadir untuk memelihara dan menumbuhkembangkan maslahat itu serta mengenyahkan segala mafsadat dan perbuatan merugikan yang merupakan lawannya. ${ }^{62}$

Para ulama ushul telah bersepaham bahwa, suatu 'urf baru dapat dijadikan sebagai salah satu dalil dalam menetapkan hukum syara' apabila memenuhi syarat-syarat seperti 'urf itu harus berlaku secara umum dalam mayoritas kalangan masyarakat dan keberlakuannya dianut oleh mayoritas masyarakat tersebut, baik itu 'urf, 'urf tersebut telah memasyarakat sebelumnya baik dalam bentuk perbuatan, perkataan, umum, dan khusus,'urf tersebut tidak bertentangan dengan dengan nash dan apa yang diungkapkan secara jelas dalam suatu transaksi atau perjanjian. ${ }^{63}$

Setelah dicermati, cukup jelas bahwa, tradisi metrae dan nyalene yang dilakukan oleh masyarakat sesuai dengan syarat-syarat 'urf yang dikemukakan di atas, untuk itu karena tidak ada sedikitpun mudharat yang timbul akibat dilaksanakannya tradisi ini, bahkan sebaliknya sangat bermakna dan bermanfaat, tentu masyarakat berkewajiban melestarikannya

\section{Kesimpulan}

\footnotetext{
${ }^{62}$ Ibid, hlm. 255.

${ }^{63}$ Wahbah al-Zuhailî, Ushûl, hlm. 837
} 
Metrae dan nyalene prosesnya berlangsung secara turun temurun sejak zaman nenek moyang hingga saat ini masih terus lestari pada masyarakat Madura. Hal ini biasa dilakukan pada masa 10 terakhir bulan Ramadhan, karena pada bulan ini berkenaan dengan kewajiban mengeluarkan zakat fitrah bagi umat muslim dan perintah membayar zakat fitrah berakhir sebelum shalat hari raya Idul Fitri dilakukan.

Penyerahan pertra dan salenan biasanya dilakukan oleh orang tua tunangan laki-laki namun ada sebagian kecil pihak laki-laki yang bertunangan mengunjungi kediaman tunangan perempuan dengan membawa petra dan salenan yang kemudian diterima oleh calon besan. Petra dan salenan berupa beras atau uang yang senilai dengan petra dan untuk salenan-nya terkadang berupa sepotong kain, seperangkat pakaian, atau uang yang cukup untuk membeli pakaian yang nantinya akan dikenakan ketika berkunjung ke rumah tunangan laki-laki saat hari raya Idul Fitri tiba.

Tradisi metrae dan nyalene dilakukan selain karena menjadi kelumrahan pada masyarakat juga, karena didorong keinginan untuk saling menolong dan membantu mengurangi beban pihak tunangan perempuan sehingga dapat mempererat hubungan keluarga antara kedua belah pihak sebab, dengan memberikan petra dan salenan disitulah terpaut kuat silaturahmi antara keduanya, rasa cinta yang tengah dirajut dapat terikat sampai saatnya melangsungkan akad nikah.

Menyerahkan petra dan salenan berarti menyiratkan bahwa pertunangannya siap diteruskan sampai memasuki waktu yang dijanjikan dalam sebuah pernikahan. Metrae dan nyalene bagi pihak laki-laki menjadi pelajaran penting arti sebuah tanggung jawab, karena kelak akan menjadi suami yang wajib menafkahi baik kepada istri dan anak-ankanya. Pihak laki-laki yang memberi petra dan salenan berarti telah menjaga kehormatan keluarganya, sehingga terbebas dari cemoohan masyarakat sekitar lebih-lebih pihak tunangan perempuan karena dianggap tidak menjalankan tradisi yang sudah berlaku umum pada masyarakat.

Kebiasaan yang dilaksanakan oleh masyarakat berupa metrae dan nyalene dapat dikategorikan pada 'urf 'amalî yaitu berupa kebiasaan masyarakat yang berkaitan dengan perbuatan. Metrae dan naylene adalah aktivitas perbuatan non verbal yang sudah mengakar pada kehidupan masyarakat dari nenek moyangnya. Sedangkan dari segi cakupannya, tradisi ini termasuk pada 'urf khash, yaitu kebiasaan khusus yang berlaku di daerah atau masyarakat tertentu dan tidak berlaku pada masyarakat lain

Metrae dan nyalene baik bentuk, cakupan dan motivasi dari pelaksananya termasuk termasuk pada 'urf shahih yaitu, kebiasaan yang berlaku di tengahtengah masyarakat dan tidak bertentangan dengan nash al-Qur'an dan Hadits, tidak menyalahi prinsip agama, tidak bertolak belakang dengan akal dan budi manusia, tidak menghilangkan kemashlahatan dan tidak pula mendatangkan kemudharatan karenanya, menjalankan dan melestarikan tradisi ini termasuk 
menjalankan prinsip agama berupa tolong menolong, mendatangkan kemashlahatan bersama sebagai penguat tali persaudaraan dan pengikat hubungan pertunangan sampai kelak menuju jenjang pernikahan, menepis anggapan jelek masyarakat berupa cacian dan makian sesuai dengan akal dan budi masyarakat

\section{Daftar Pustaka}

'Asqalani, Al-Hafidz Ibnu Hajar al-. Bulûghul Marâm. Surabaya: Al-Hidayah, tt Adi, Rianto. Metodologi Penelitian Sosial dan Hukum. Jakarta: Granit, 2004 al-Baihaqî, Abu Bakar. Al-Sunan al-Kubrâ. Juz 6. Bairut: Dâr al-Kutub al-'Ilmiyah, 2003

al-Bukhari, Muhammad bin Ismail Abu Abdillah. Shahih al-Bukhari. Juz. 2. tt: Dar Thuq al-Najah, $1422 \mathrm{H}$

al-Bukhari, Muhammad bin Ismail Abu Abdillah. Shahih Bukhari. Vol. 7. Dar Thuq al-Najah, 1422

al-Khin, Mustafa. al-Figh al-Minhâjî alâ Madzhab al-Imâm al-Syafi'. Juz 6. Damaskus: Dar al-Qalam, 1982

al-Naisabûrî, Muslim bin al-Hajjâj. Musnad al-Shahîh al-Mukhtashar bi Naql al-'Adl 'an al-'Adl Ila Rasulillah. Juz. 2. Bairut: Dâr Ihyâ' al-Turâts al-'Arabî, tt

al-Zuhailî, Wahbah. Al-Figh al-Islãmĩ wa Adillatuhũ. Juz. 9. Damaskus: Dar al-Fikr, 2004

al-Zuhailî, Wahbah. Ushûl al-Fiqh al-Islamî. Vol. 2. Syiria: Dar al-Fikr, 2001

As-Subki, Ali Yusuf. Figh Keluarga. Jakarta: Amzah, 2012

Baihaqî, Abu Bakar al-. Al-Sunan al-Kubrâ. Juz 6. Bairut: Dâr al-Kutub al-'Ilmiyah, 2003

Bakry, Nasar. Problematika Pelaksanaan Figh Islam. Jakarta: PT Raja Grafindo Persada, 1994

Bakry, Nazar. Ushul Fiqh. Jakarta: PT Raja Grafindo Persada, 2003

Dahlan,Abd. Rahman. Ushul Figh. Jakarta: Amzah, 2014

Departemen Agama RI. Al-Qur'ân dan Terjemahnya. Jakarta: PT. Hati Emas, 2014

Hambal, Abu Abdilah Ahmad bin Muhammad Ahmad bin. Musnad Ahmad Ibn Hambal, Juz 29. tt: Muassasah al-Risalah, 2001

Hawwas, Abdul Wahhab Sayyed. Fiqh Munakahat. Jakarta: Amzah, 2011

Khalaf, Abd Wahhab. Ilmu Ushûl al-Figh. tt. Dâr al-Qalam,1978

Mãjah, Ibn. Sunan Ibn Mãjah, Juz. 2. tt: Dar Ihyã' al-Kutub al-Ilmiyah, tt

Moleong, Lexy J. Metodologi Penelitian Kualitatif. Bandung: Remaja Rosdakarya, 1990

Mudjib, Abdul. Kaidah-kaidah Ilmu Figh. Jakarta: Kalam Mulia, 2001

Qaradhawi, Yusuf al-. 7 Kaidah Utama Figh Muamalat. Jakarta: Pustaka AlKautsar, 2014

Safioedin, Asis. Kamus Bahasa Madura-Indonesia. Surabaya: CV. Kanendra Suminar 
ADHKI: Journal of Islamic Family Law

Sahrani, Tihami dan Sohari. Fikih Munakahat. Jakarta: Rajawali Pers, 2010

Saibani, Ahmad bin Hanbal Abu Abdullah al. Musnad al-Imam Ahmad bin Hambal. Juz.1. Kairo: Muassasah Qartubah, tt

Sirajuddin M, "Eksistensi 'Urf Sebagai Sumber Pelembagaan Hukum Nasional", Madania, Vol. 19, No. 1, Juni, 2015

Sugiyono. Metode Penelitian Kuantitatif Kualitatif dan RED. Bandung: Alfabeta, 2009

Syarifuddin, Amir. Ushul Figh. Vol. 2. Jakarta: Kencana Prenadamedia, 2008

Tanzeh. Metodologi Penelitian Praktis. Yogyakarta: Teras, 2011

Tirmîdzî, Muahammad bin Îsâ Abû Îsâ al-. Al-Jâmi' al-Shâhîh Sunan al-Tirmîdzî. Juz 4. Bairut: Dâr Thyâ' al-Turâts al-'Arabî, tt 